Mr Dejan Ivković, major, dipl. inž. Generalštab Vojske Srbije

Uprava J-2,

Beograd

\section{REZULTATI OBRADE SIGNALA U PROJEKTOVANIM BLOKOVIMA PRIJEMNIKA SOFTVERSKOG RADARA}

UDC: 621.396 .96

Rezime:

U radu su prikazani rezultati obrade signala u ranije projektovanim softverskim modulima radarskog prijemnika. Prvo su navedeni rezultati merenja realnog klatera bez prisustva ciljeva $u$ vazdušnom prostoru, zatim rezultati detekcije simuliranih ciljeva u prisustvu realnog klatera $i$, na kraju, rezultati detekcije tri realna cilja u vazduhu. Svi parametri pri merenju klatera $i$ detekcije simuliranih $i$ realnih ciljeva prikazani su tabelarno, a rezultati grafički. Na osnovu analize prikazanih rezultata može se zaključiti da projektovani softverski moduli radarskog prijemnika dobro emuliraju rad postojećih hardverskih blokova realnog radara.

Ključne reči: softverski radar, realni klater, simulirani cilj, realni cilj.

\title{
RESULTS OF THE SIGNAL PROCESSING IN DESIGNED RECEIVER BLOCKS OF SOFTWARE RADAR
}

Summary:

This paper presents the results of signal processing in previously designed software modules of radar receivers. The measurement procedure is described briefly. The results of measuring real clutter without aerial targets are followed by the results of detecting simulated targets in the presence of real clutter. Finally, the results of the detection of three real targets in the air are presented. All parameters of the clutter measurement and the detection of targets, both simulated and real, are given in tables while the results are showed graphically. On the basis of the analysis of the obtained results, it can be concluded that the designed software modules of the radar receiver successfully emulate the operation of existing hardware blocks of real radars.

Key words: software radar, real clutter, simulated target, real target.

\section{Uvod}

Da bi se verifikovala predložena rešenja funkcionalnih blokova softverskog radarskog prijemnika u [1] i [2], bilo je neophodno izmeriti radarske signale, a zatim uporediti rezultate obrade signala $u$ projektovanim blokovima sa rezultatima obrade $u$ realnom radaru. Merenje je izvršeno na radaru ŽIRAFA, pre svega zbog toga što spada u grupu tipičnih konvencionalnih radara s digitalnom ob- radom signala. To znači da će sva rešenja softverskih modula ovog radara biti primenjiva i kod ostalih vojnih ili civilnih konvencionalnih radara, uz eventualne manje modifikacije i prilagođavanja konkretnom radarskom sistemu. Pored toga, radar ŽIRAFA bio je dostupan i van operativne upotrebe u dužem periodu. Tokom priprema za merenje radarskih signala i njihovu obradu u projektovanim blokovima radarskog prijemnika postojale su dve polazne pretpostavke. 


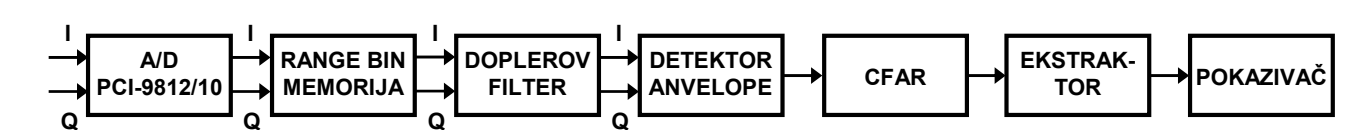

Sl. 1 - Deo radarskog prijemnika za obradu signala sa softverski modelovanim blokovima

Postojeća hardverska platforma (kartica PCI-9812/10) omogućava akviziciju radarskog signala u realnom vremenu. Takođe, postojeća računarska platforma i softversko okruženje omogućavaju akviziciju i smeštaj podataka u realnom vremenu, ali ne i obradu memorisanih podataka. Obrada podataka mora biti izvedena u tzv. offline režimu, jer je celokupna implementacija softverskih modula urađena u programskom paketu MATLAB, na jednom personalnom računaru.

Softverski moduli radarskog prijemnika, definisani i opisani u [1] i [2], a prikazani na slici 1, omogućiće takvu obradu radarskih signala čiji rezultati potpuno odgovaraju rezultatima realnog radarskog sistema (ŽIRAFA).

Praktična provera rada svih projektovanih softverskih modula radara izvršena je pomoću dva osnovna scenarija.

Prvi scenario podrazumeva detekciju simuliranih pojedinačnih ciljeva $u$ realnom klateru. Pretpostavka je da će karakteristike cilja koji se simulira, u skladu sa prethodno opisanim matematičkim modelom, u velikoj meri odgovarati karakteristikama realnog cilja. Rezultati koji se u ovom scenariju očekuju od projektovanog softverskog radarskog prijemnika su:

- uspešna detekcija pojedinačnih simuliranih ciljeva u realnom klateru, $\mathrm{i}$ ciljeva.
Drugi scenario je značajniji za proveru rada projektovanih softverskih modula. On podrazumeva detekciju realnih pojedinačnih ciljeva. Pretpostavka je da će realni cilj biti mlazni putnički avion koji leti na redovnoj liniji, tako da nisu poznati parametri njegovog leta. U ovom scenariju rezultati koji se očekuju od projektovanih softverskih modula radarskog prijemnika su:

- uspešna detekcija pojedinačnih realnih ciljeva, i

- poboljšanje detekcije realnih ciljeva.

Pretpostavka je da se pri detekciji koristi radarski prijemnik koji u svom sastavu ima fleksibilni CFAR procesor po pitanju algoritma detekcije i veličine prozora detekcije.

\section{Način rada}

Tokom rada na radaru ŽIRAFA (slika 2) izvršeno je više merenja sa opremom koja je prikazana na slici 3a. Pored opisane akvizicione kartice PCI-9812/10 korišćen je personalni računar sa sledećim karakteristikama:

$\mathrm{GHz}$,

- procesor AMD Athlon - 1.53

- matična ploča ASUS AGP8X,

- RAM 512 MB,

- operativni sistem - Microsoft Windows XP Professional. 


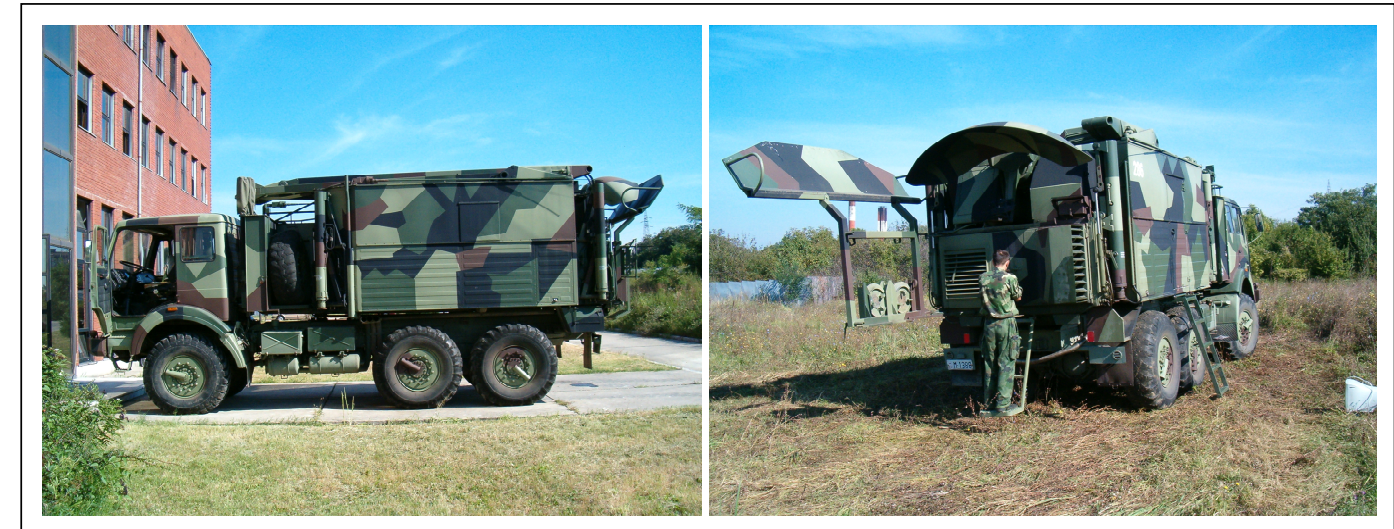

Sl. 2 - Radar ŽIRAFA
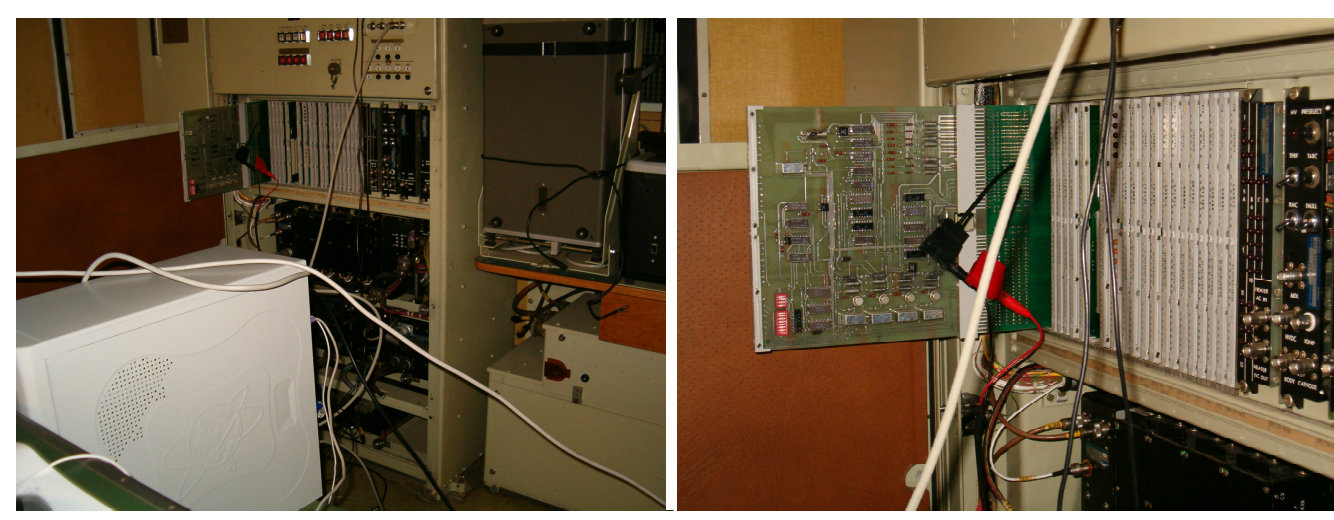

a)

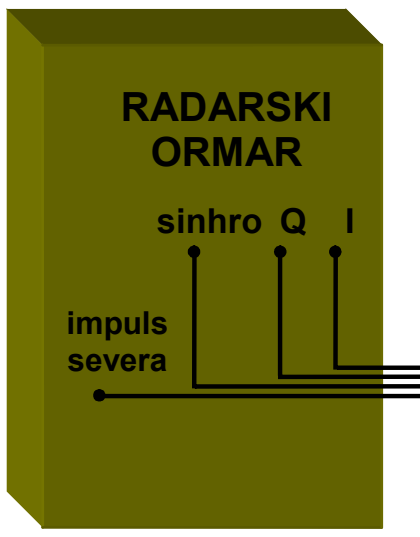


Na blok-šemi merenja (slika 3b) prikazan je, pored računara i akvizicione kartice, radarski ormar u kojem se nalaze izvori za napajanje, predajnik i prijemnik radara ŽIRAFA. Na radarskom ormaru postoje izvodi na kojima se nalaze i izlazni signali I i Q grane IQ-demodulatora i izlazni signal generatora impulsne frekvencije (,,sinhro“). Impuls severa dobijen je preko kartice sa oznakom ROE 124 2105/01, koja se nalazi u sastavu radarskog ormara, a bitan je zbog pravilnog formiranja paketa radarskih podataka u RANGE BIN memoriji.

Pri svakom merenju u realnom vremenu obavljena je akvizicija podataka i njihovo memorisanje, a obrada signala je, usled obrade na personalnom računaru, izvođena u ,offline“ režimu.

U vreme osmatranja vazdušnog prostora i izvođenja svih merenja nije bilo klatera koji su poticali od kiše i oblaka, a nije bilo ni aktivnog ometanja. Postojao je samo klater od reljefa, šume i okolnih zgrada.

Prvo je meren realni klater u odsustvu realnih ciljeva i analizirani su rezultati obrade, a zatim su realnom klateru superponirani signali simuliranih ciljeva po matematičkom modelu predstavljenom u [2], kako bi se verifikovao rad svih projektovanih softverskih modula prijemnika konvencionalnog radara. $\mathrm{Na}$ kraju je izvršen eksperiment sa realnim ciljevima, što je predstavljalo pravu proveru ispravnosti rada projektovanog softverskog modela. Realni ciljevi bili su avioni iz civilnog avio-saobraćaja koji su leteli na svojim redovnim linijama.

\section{Merenje realnog klatera}

Radi verifikacije pravilnosti rada projektovanih funkcionalnih blokova radarskog prijemnika obavljena su merenja na radaru ŽIRAFA, koja su podrazumevala akviziciju realnog klatera. Frekvencija odabiranja A/D konvertora bila je 2 $\mathrm{MHz}$, jer su sinhronizacioni impulsi iz generatora impulsne frekvencije veoma uski, pa na nižim frekvencijama dolazi do preskakanja pojedinih sinhro-impulsa, što remeti pravilno formiranje podataka $u$ RANGE BIN memoriji. Pošto je frekvencija odabiranja signala na izlazu IQdemodulatora oko osam puta veća od stvarne frekvencije odabiranja A/D konvertora u radaru ŽIRAFA, a da bi rezultati bili relevantni, CFAR procesor projektovan je tako da je osam puta većeg reda nego original. To znači da se ispituju 64 susedna bina daljine oko test bina [2]. Za verovatnoću lažnog alarma uzeta je standardna vrednost od $10^{-6}$, pa je faktor skaliranja, $\mathrm{T}_{\mathrm{h}}$, imao vrednost od 4,623 [2]. Akvizicija klatera urađena je za 5900 predajnih impulsa pri promenljivoj frekvenciji ponavljanja impulsa, a širina predajnog impulsa bila je $6 \mathrm{~s}$, što znači da je domet radara bio $40 \mathrm{~km}$. Frekvencija visokofrekventnog nosioca predajnog signala bila je 5,4 GHz. U tabeli 1. dat je pregled svih parametara akvizicije podataka.

\begin{tabular}{|l|l|}
\multicolumn{2}{c}{ Parametri akvizicije realnog klatera } \\
\begin{tabular}{|l|l|}
\hline \multicolumn{1}{|c|}{ Parametar } & \multicolumn{1}{c|}{ Vrednost } \\
\hline Frekvencija odabiranja & $\mathrm{f}_{\mathrm{sm}}=2 \mathrm{MHz}$ \\
\hline Broj ćelija CFAR procesora & $2 \mathrm{n}=64$ \\
\hline Verovatnoća lažnog alarma & $\mathrm{P}_{\mathrm{fa}}=10^{-6}$ \\
\hline Faktor skaliranja & $\mathrm{T}_{\mathrm{h}}=4,623$ \\
\hline Broj predajnih impulsa & $\mathrm{N}=5900$ \\
\hline Širina predajnog impulsa & $=6 \mathrm{~s}$ \\
\hline Frekvencija nosioca predajnog impulsa & $\mathrm{f}_{\mathrm{t}}=5,4 \mathrm{GHz}$ \\
\hline Frekvencija ponavljanja impulsa & promenljiva \\
\hline
\end{tabular}
\end{tabular}




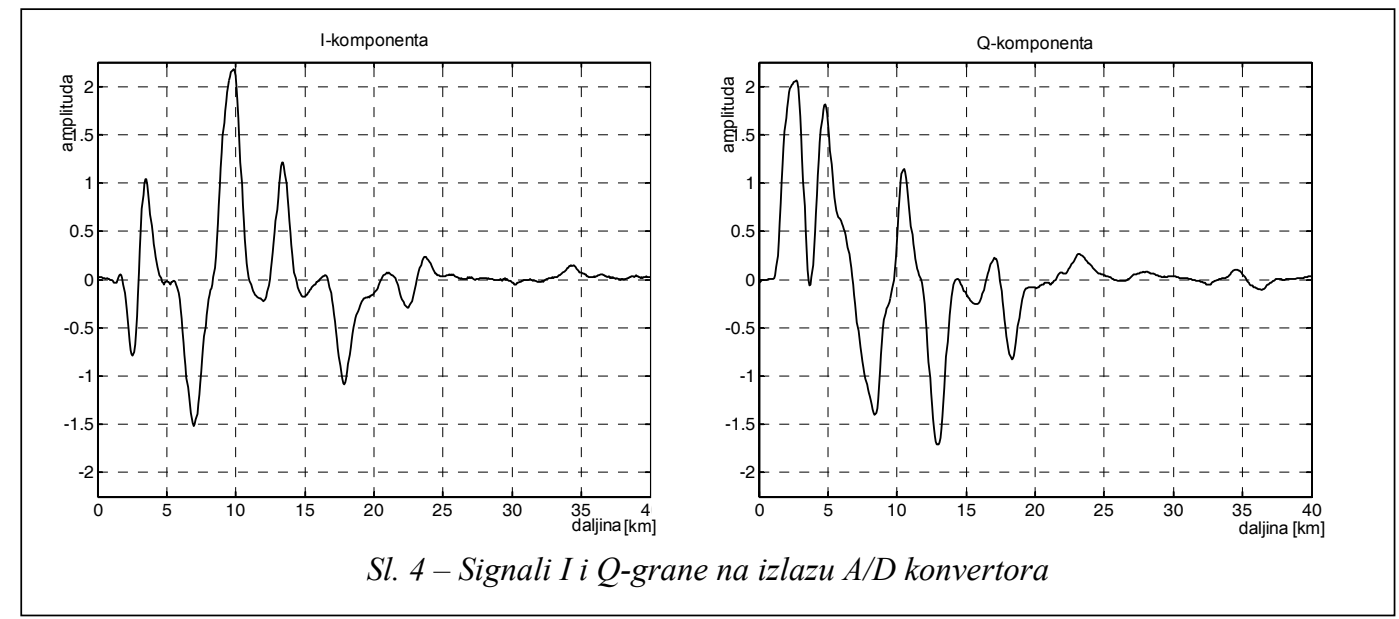

Na slici 4 prikazan je oblik signala I video signal za opseg daljina od 0 do 40 i Q-grane na izlazu A/D konvertora PCI- $\mathrm{km}$. U gornjem delu slike 5 nalazi se pri9812/10 za jedan predajni impuls radara, kaz u tri dimenzije, a u donjem delu slike a na slici 5 prikazan je kompletan digital- prikazan je radiogram sirovog video signo neobrađeni prijemni signal, tzv. sirovi nala.

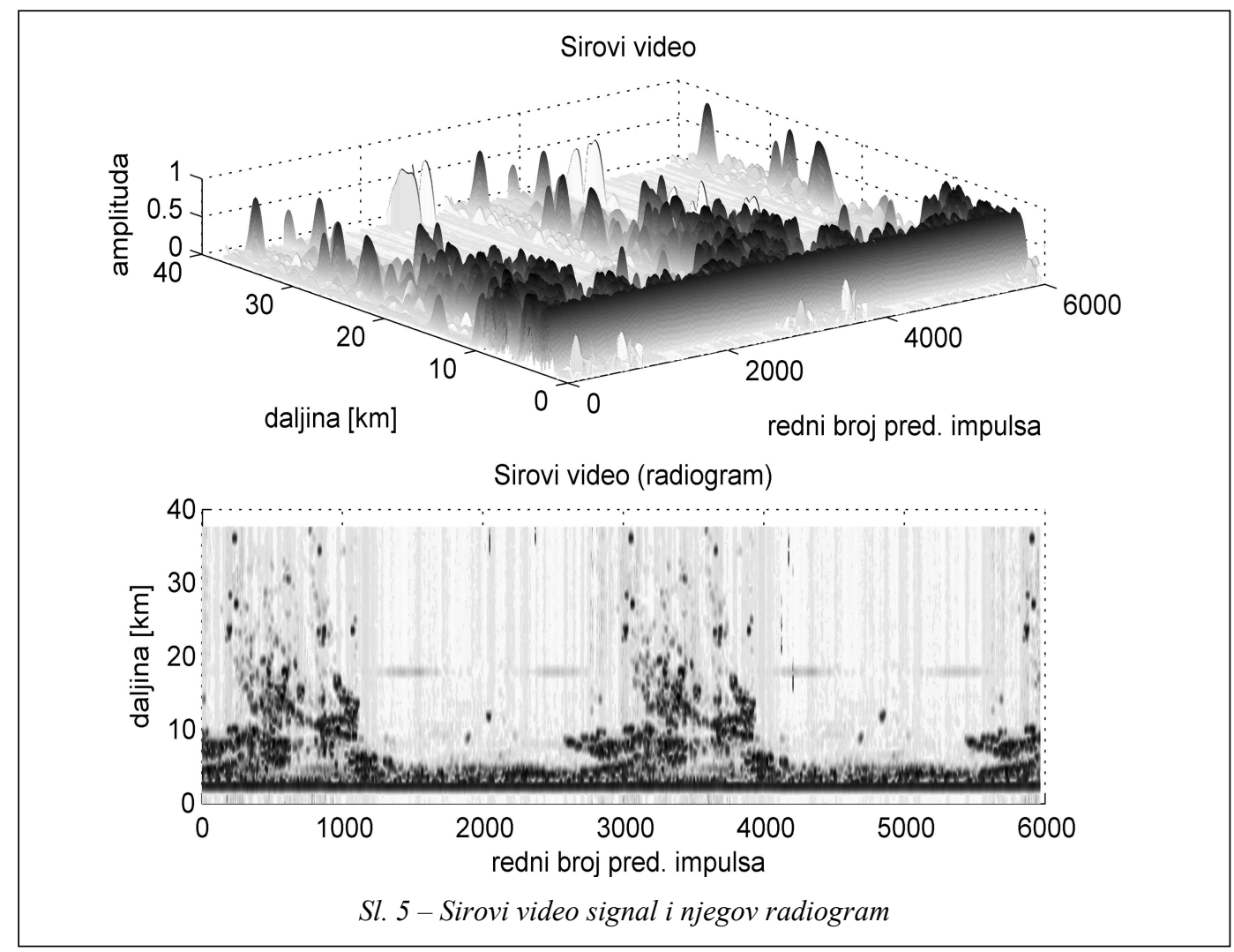




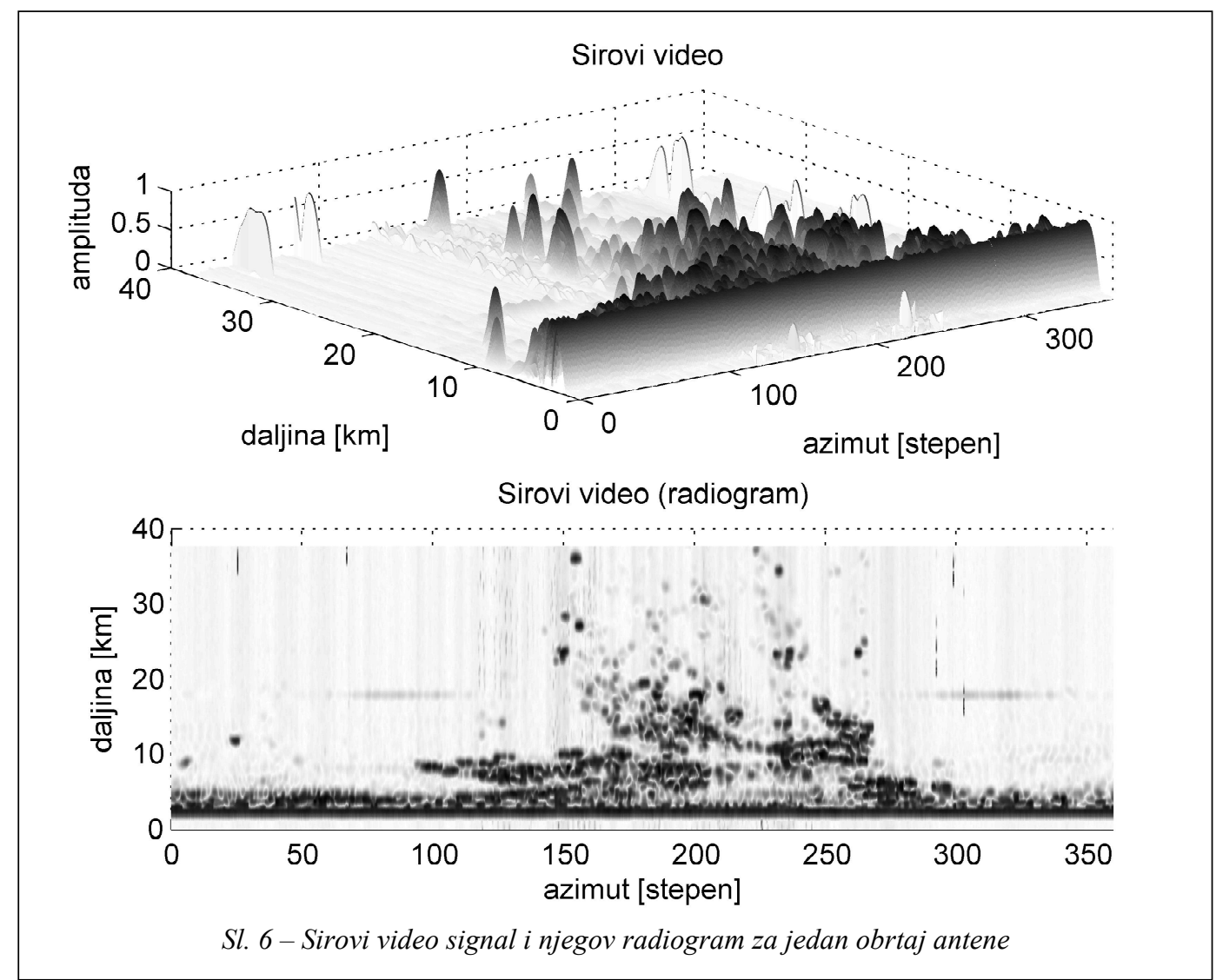

Uočava se da se posle određenog broja predajnih impulsa slika sirovog videa ponavlja, što znači da je antena pri merenju načinila više od jednog obrtaja.

Između 1. i 1000. predajnog impulsa uočava se zona veoma jakog klatera, sa velikim brojem stalnih odraza, koja se ponavlja od 3000. do 4000. predajnog impulsa.

$\mathrm{Na}$ slici 6 prikazan je sirovi video signal za jedan obrtaj antene, a na x-osi je predstavljen azimut $\mathrm{u}$ stepenima. $\mathrm{U}$ ovom obrtaju antene nije bilo pokretnih ciljeva u osmatranoj zoni, što će i potvrditi obrada signala u projektovanim funkcionalnim blokovima.
Posle filtriranja u Doplerovom filteru [2] signal se prosleđuje na detektor anvelope, a signal na njegovom izlazu prikazan je na slici 7. Uočava se da su stalni odrazi uglavnom dobro potisnuti, osim nekih komponenata signala oko azimuta od $25^{\circ}, 65^{\circ}$ i $300^{\circ}$.

Signal sa detektora anvelope dolazi na ulaz CFAR procesora, koji pomoću opisanog algoritma u [2] detektuje da li u ispitivanom binu daljine postoji ili ne postoji cilj. Signal na njegovom izlazu prikazan je na slici 8. Uočava se samo manji broj lažnih detekcija od kojih nijedna ne predstavlja pokretni cilj, što znači da je CFAR procesor pravilno obradio ulazni signal. 

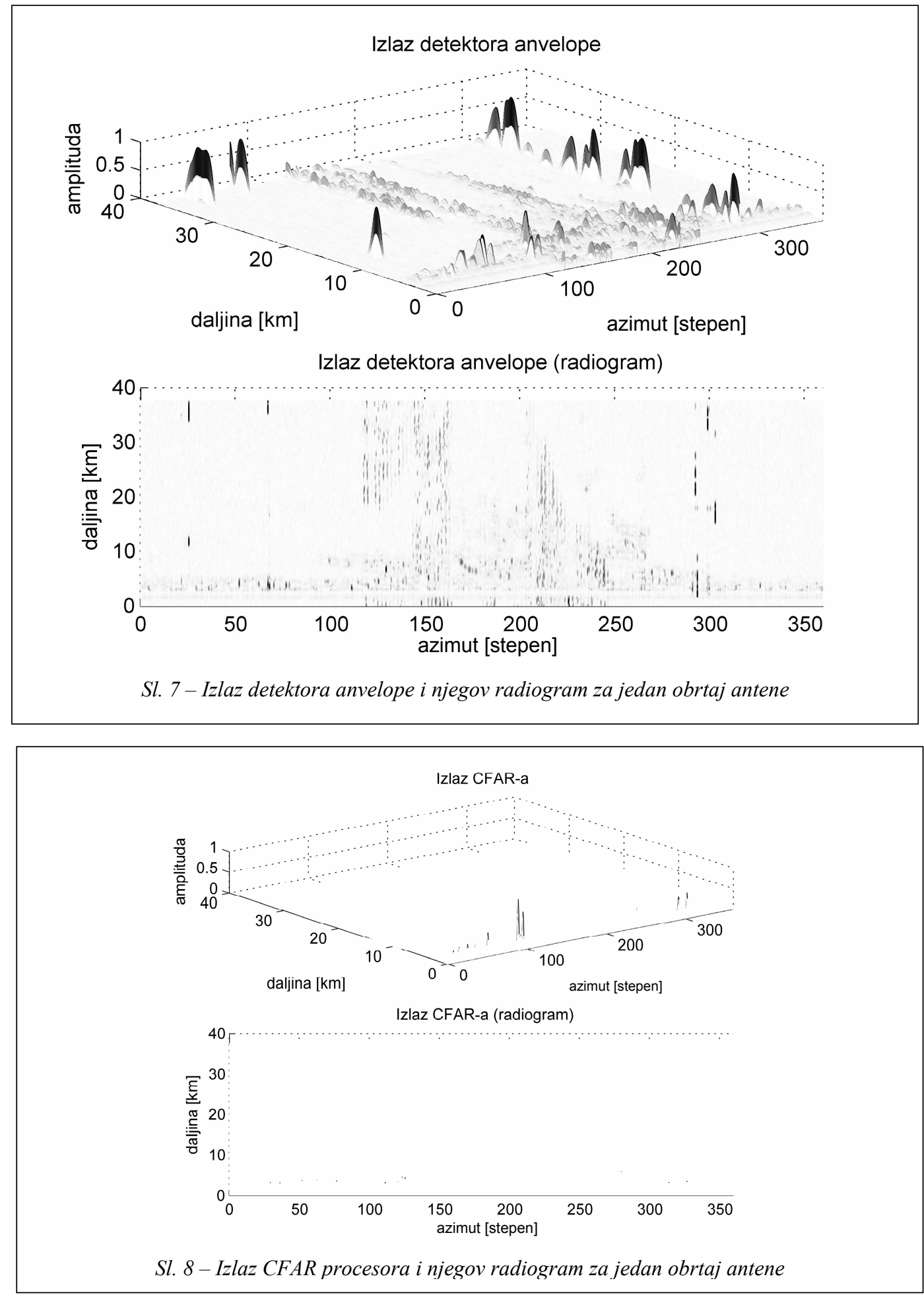


\section{Detekcija simuliranih ciljeva u realnom klateru}

Simulirano je postojanje tri cilja $\mathrm{u}$ realnom klateru. Matematički model simuliranih ciljeva odgovara modelu koji je prikazan u [2], a osnovni parametri ciljeva dati su u tabeli 2 .

\section{Parametri ciljeva}

\begin{tabular}{|l|c|c|c|}
\hline \multicolumn{1}{|c|}{ Parametar } & Cilj 1 & Cilj 2 & Cilj 3 \\
\hline Amplituda $\mathrm{U}_{\mathrm{s}}$ & 2 & 1,5 & 4 \\
\hline Doplerova frekvencija $\mathrm{f}_{\mathrm{d}}$ & $1500 \mathrm{~Hz}$ & $6000 \mathrm{~Hz}$ & $3000 \mathrm{~Hz}$ \\
\hline Daljina R & $8 \mathrm{~km}$ & $15 \mathrm{~km}$ & $25 \mathrm{~km}$ \\
\hline Azimut & $125^{\circ}$ & $190^{\circ}$ & $300^{\circ}$ \\
\hline
\end{tabular}

Sirovi video signal sa simuliranim ciljevima prikazan je na slici 9. Od tri pokretna cilja jedino se cilj 3 može primetiti u sirovom video signalu, dok su cilj 1 i cilj 2 potpuno maskirani, jer se nalaze $\mathrm{u}$ oblastima jakog klatera, a po amplitudi su čak i nešto malo ispod njegovog nivoa. Posle filtriranja u Doplerovom filteru situacija se menja. Na slici 10 jasno se uočavaju simulirani ciljevi, ali pored njih postoje i neki drugi odrazi. Posle obrade signala u CFAR procesoru ostaju samo pokretni ciljevi. Izlaz iz CFAR procesora za pun obrtaj antene prikazan je na slici 11 .

Efekat obrade signala u projektovanim blokovima softverskog radarskog prijemnika može se bolje uočiti na slici 12, gde je osa azimuta selektovana u opsegu od $170^{\circ}$ do $210^{\circ}$. U tom sektoru klater je veoma jak, pa se cilj 2 veoma teško uočava u sirovom video signalu. Tek na izlazu iz CFAR procesora potpuno jasno se uočava cilj 2 na azimutu $190^{\circ}$ i daljini od $15 \mathrm{~km}$.

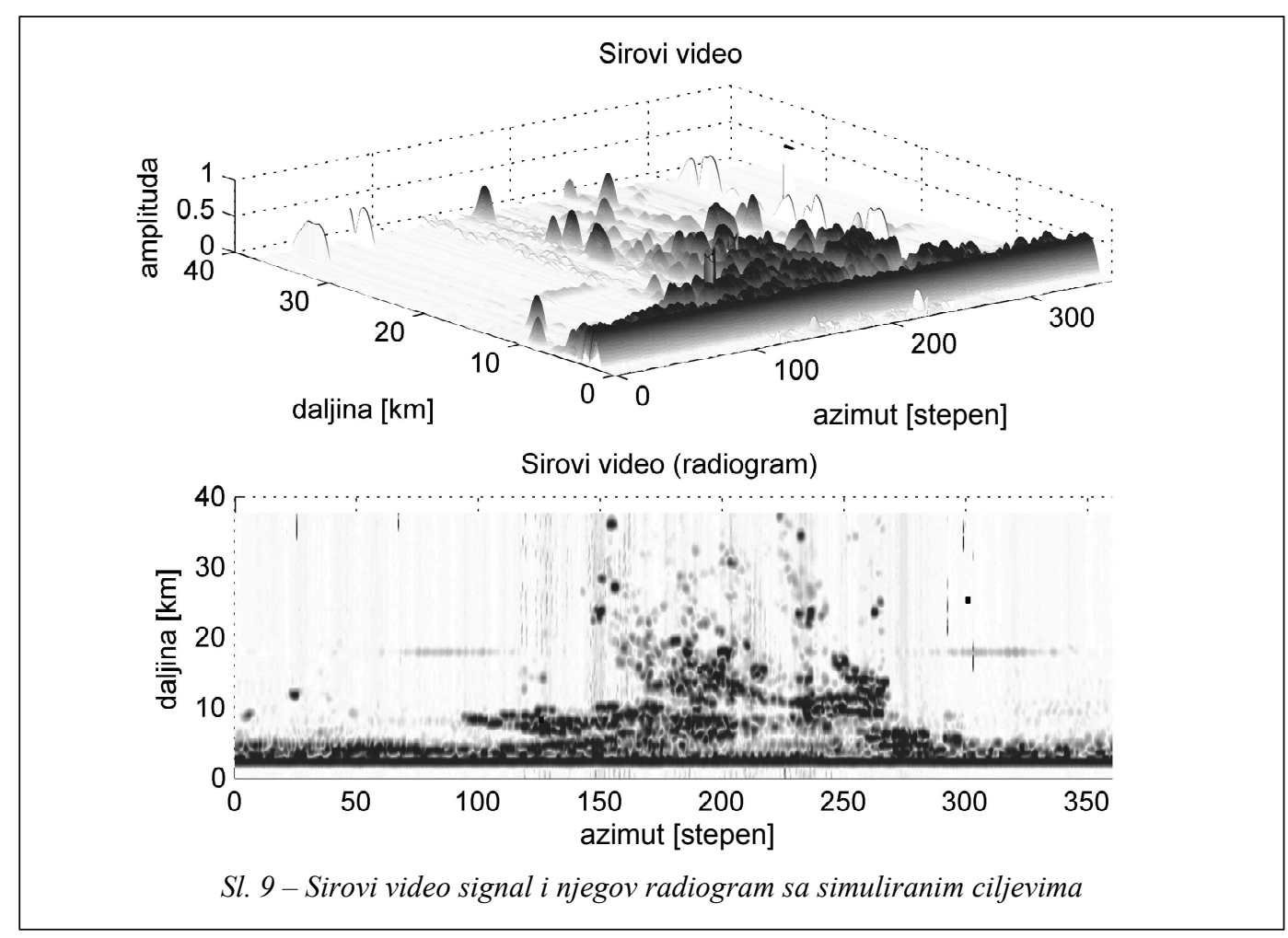



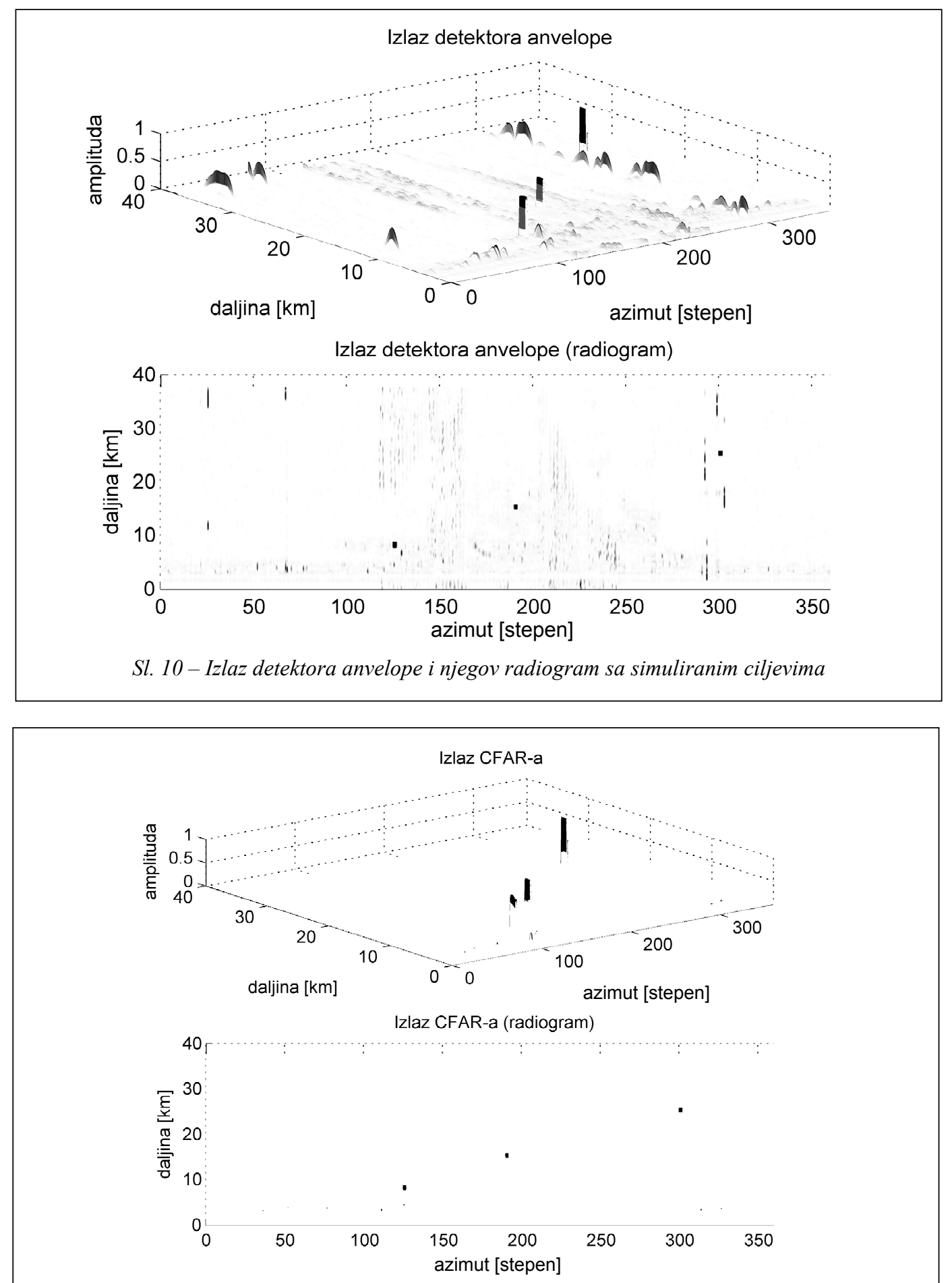

Sl. 11 - Izlaz CFAR procesora i njegov radiogram sa simuliranim ciljevima 

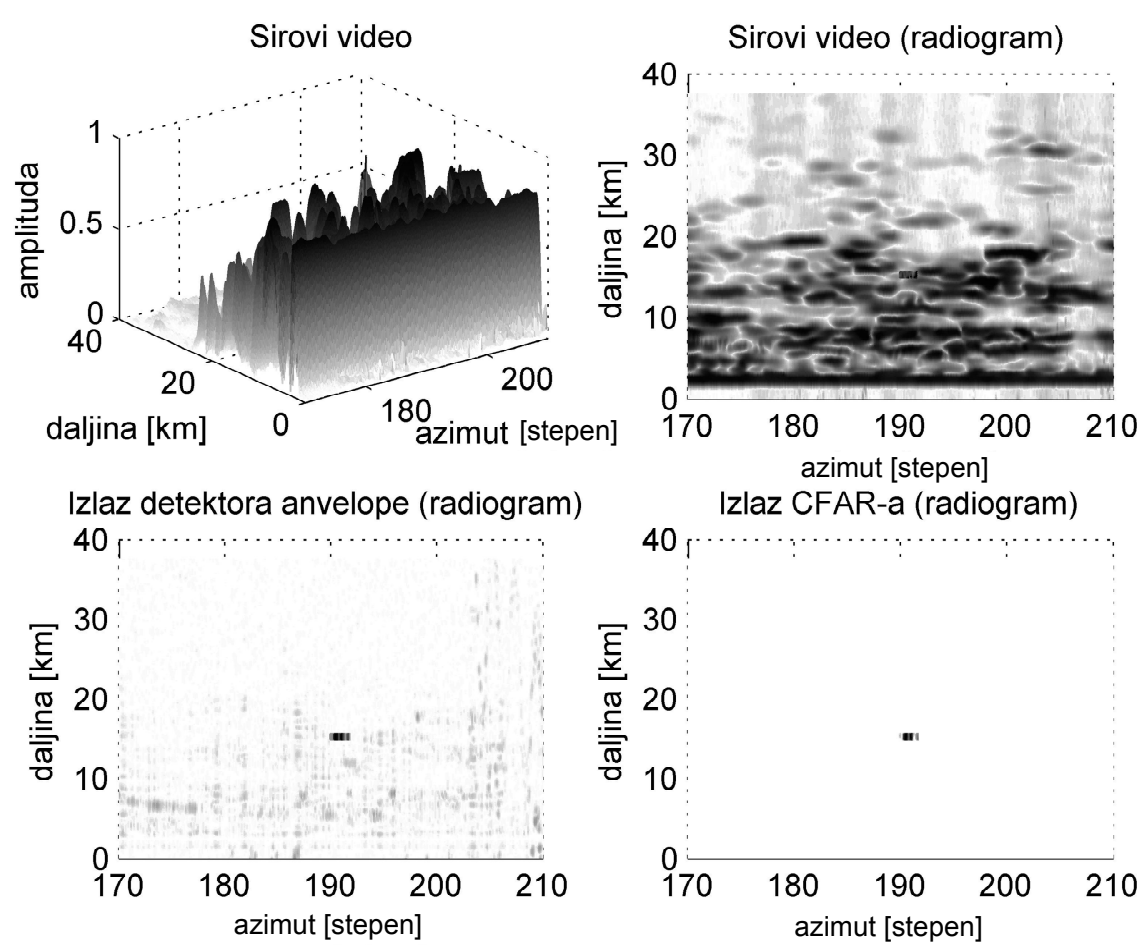

Sl. 12 - Sirovi video signal, izlaz detektora anvelope i CFAR procesora selektovan po azimutu (cilj 2)

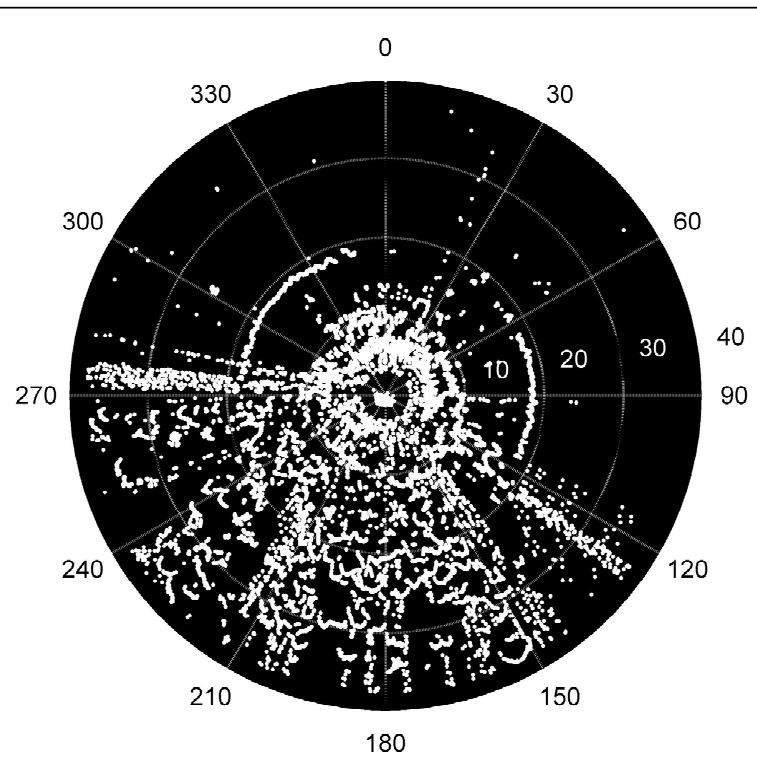

Sl. 13 - Izgled softverski modelovanog panoramskog pokazivača (sirovi video signal) 


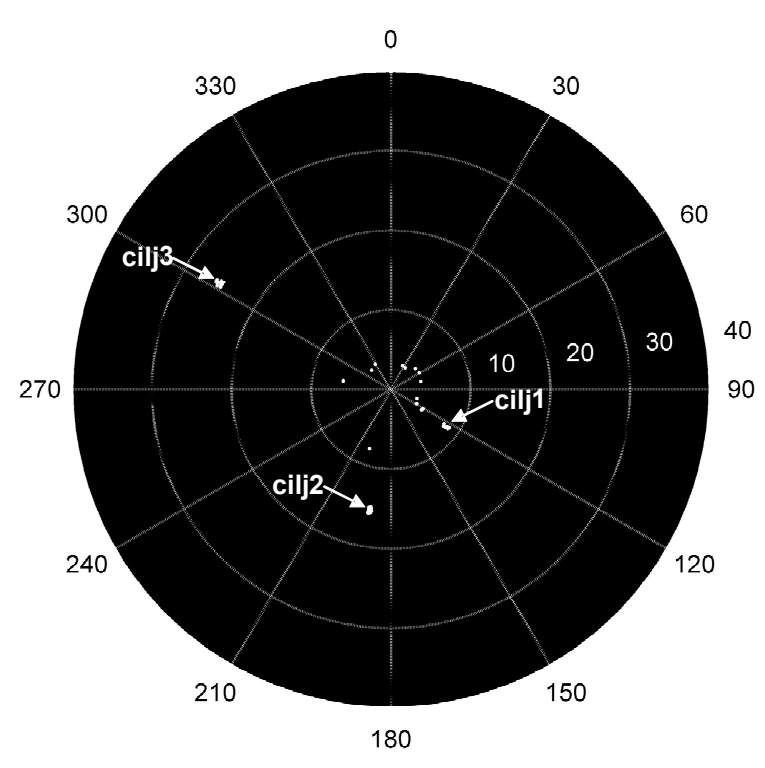

Sl. 14 - Izgled softverski modelovanog panoramskog pokazivača (sintetički video signal)

Signali sa izlaza CFAR procesora dolaze na ulaz ekstraktora [2] koji određuje koordinatu svakog detektovanog cilja, što znači da se određuju azimut i daljina svakog cilja. Koordinate ciljeva prosleđuju se softverski modelovanom panoramskom pokazivaču. Na slici 13 prikazan je izgled panoramskog pokazivača kada se prikazuje sirovi video signal, a na slici 14 je panoramski pokazivač na kojem je prikazan digitalno obrađeni signal (sintetički video signal). Kao i na slici 9 , i na slici 13 uočava se samo cilj 3 na azimutu $300^{\circ}$ i daljini $25 \mathrm{~km}$, dok se ostali ciljevi ne mogu razlikovati od klatera. Na slici 14 lako se uočavaju svi ciljevi iz tabele 2. Na pokazivaču bi se slika menjala posle svakog obrtaja antene.

$\mathrm{Na}$ osnovu prikazanih kvalitativnih rezultata zaključujemo da softverski mo- delovani funkcionalni blokovi radarskog prijemnika dobro emuliraju rad realnog prijemnika radara ŽIRAFA.

\section{Detekcija realnih ciljeva}

Pravu verifikaciju ispravnosti rada projektovanih funkcionalnih blokova softverskog radarskog prijemnika predstavlja detekcija realnih ciljeva u realnom klateru. Zbog toga je dodatno meren radarski signal pri postojanju realnih ciljeva.

Obavljena su dva merenja realnog radarskog signala prema opisanoj šemi merenja (slika 3b). Frekvencija ponavljanja predajnih impulsa bila je $2350 \mathrm{~Hz}$, a frekvencija nosioca u impulsu predajnog signala trajanja $\tau=6 \mu \mathrm{s}-5,4 \mathrm{GHz}$. U tabeli 3 prikazani su svi parametri akvizicije realnih ciljeva. 
Tabela 3 ma. Podaci o brzini i visini leta nisu bili

Parametri akvizicije realnih ciljeva

\begin{tabular}{|l|l|}
\hline \multicolumn{1}{|c|}{ Parametar } & \multicolumn{1}{|c|}{ Vrednost } \\
\hline Frekvencija odabiranja & $\mathrm{f}_{\mathrm{sm}}=2 \mathrm{MHz}$ \\
\hline Broj ćelija CFAR procesora & $2 \mathrm{n}=64$ \\
\hline Verovatnoća lažnog alarma & $\mathrm{P}_{\mathrm{fa}}=10^{-6}$ \\
\hline Faktor skaliranja & $\mathrm{T}_{\mathrm{h}}=4,623$ \\
\hline Broj predajnih impulsa & $\mathrm{N}=5900$ \\
\hline Širina predajnog impulsa & $=6 \mathrm{~s}$ \\
\hline $\begin{array}{l}\text { Frekvencija nosioca predajnog } \\
\text { impulsa }\end{array}$ & $\mathrm{f}_{\mathrm{t}}=5,4 \mathrm{GHz}$ \\
\hline Frekvencija ponavljanja impulsa & $\mathrm{f}_{\mathrm{r}}=2350 \mathrm{~Hz}$ \\
\hline
\end{tabular}

Pri prvom merenju postojala su dva realna cilja. Oba cilja bila su putnički mlazni avioni koji su leteli na redovnim linijapoznati. Prvi cilj nalazio se u oblasti jakog klatera, dok je drugi bio izvan te oblasti.

Pri drugom merenju postojao je samo jedan realni cilj. Bio je to putnički mlazni avion, koji je leteo na relativno malom rastojanju (oko $10 \mathrm{~km}$ ) od radara ŽIRAFA, ali se nalazio u oblasti veoma snažnog klatera, tako da se bez primene digitalne obrade signala nije mogao uočiti na radarskom pokazivaču. Podaci o brzini i visini leta, takođe, nisu bili poznati.

Sirovi video signal i signal na izlazu CFAR procesora, za prvo merenje, prikazani su na slici 15 .

$\mathrm{Na}$ radiogramu sirovog video signala nemoguće je razlikovati postojeće realne ciljeve od stalnih odraza. Međutim, nakon digitalne obrade signala u projektovanim softverskim modulima potiskuju se signali stalnih odraza, tako da su dva realna cilja jasno
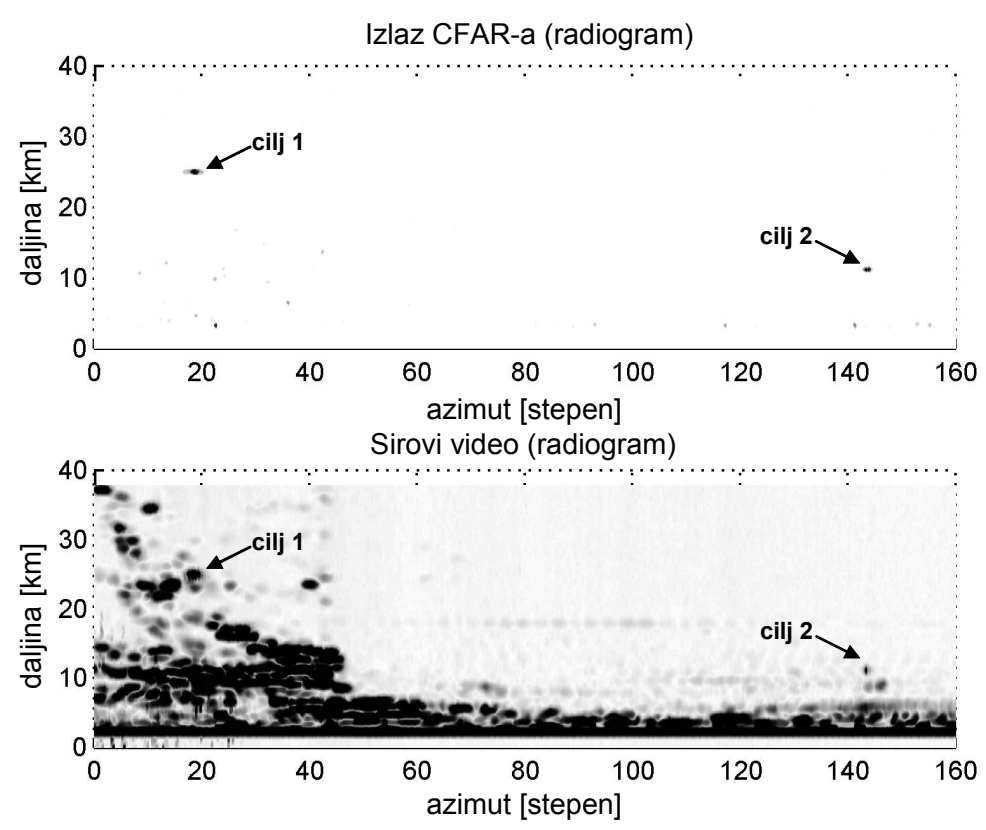

Sl. 15 - Sirovi video signal i izlaz $C F \bar{A} R$ procesora sa realnim ciljevima 

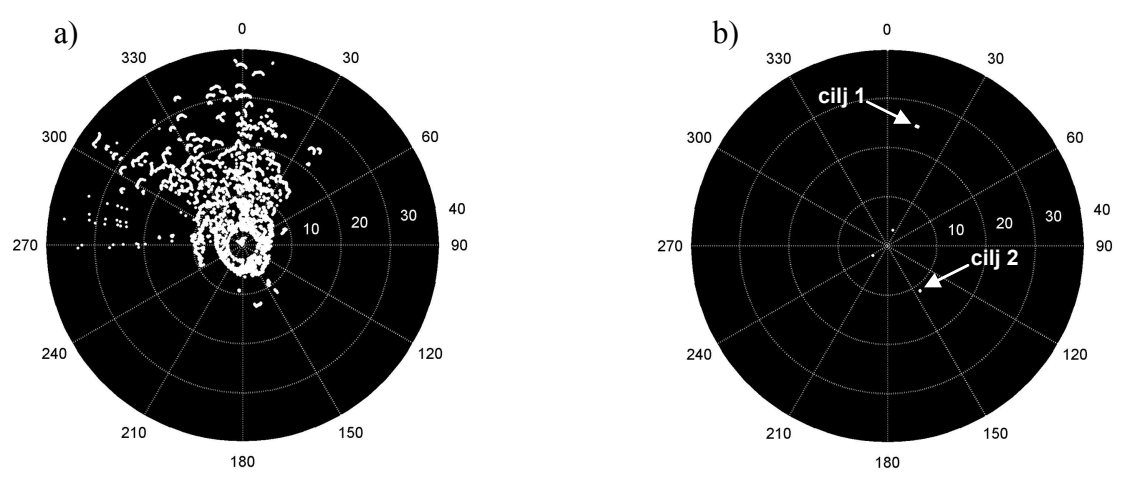

Sl. 16 - Softverski modelovani panoramski pokazivač sa realnim ciljevima: a) sirovi video signal; b) sintetički video signal

vidljiva na izlazu CFAR procesora, $\mathrm{i}$ to cilj 1 na azimutu $19^{\circ}$ i daljini $25 \mathrm{~km}$ i cilj 2 na azimutu $144^{\circ}$ i daljini $11 \mathrm{~km}$. Slični zaključci mogu se izvesti kada se uporede slike na panoramskom pokazivaču. Na slici 16b, pored dva detektovana realna cilja može se primetiti nekoliko lažnih ciljeva koji su posledica jakog signala klatera u blizini radara.
Pod istim uslovima obavljeno je i drugo merenje realnog radarskog signala, kada je izvršena akvizicija jednog realnog cilja. Sirovi video signal i izlazni signal CFAR procesora prikazani su na slici 17. Osa azimuta selektovana je u opsegu od $250^{\circ}$ do $285^{\circ}$, da bi se bolje uočio efekat digitalne obrade realnog ra-
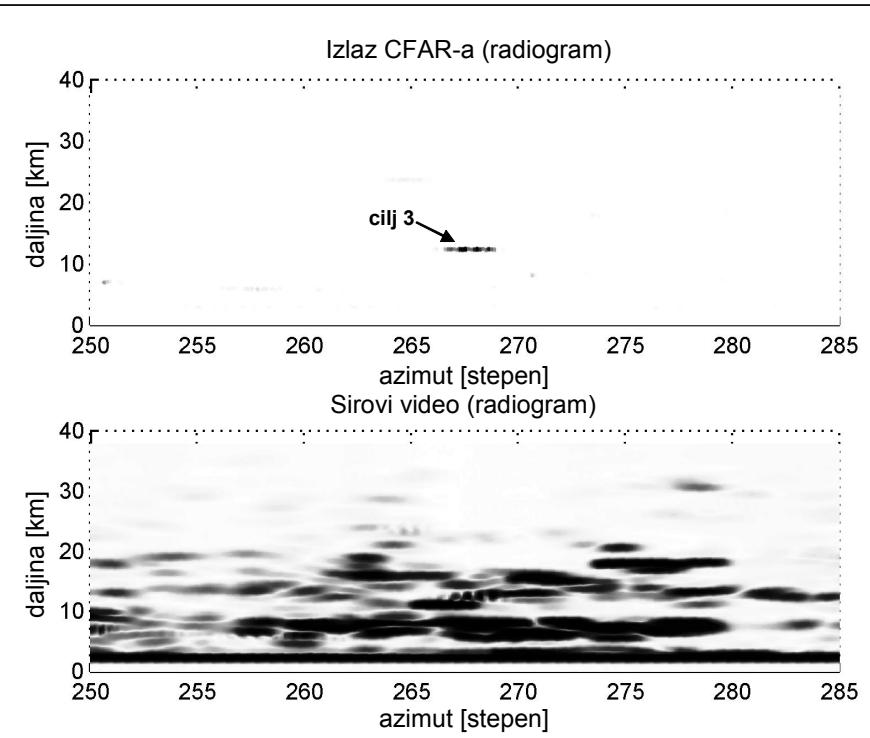

Sl. 17 - Sirovi video signal i izlaz CFAR procesora sa realnim ciljem 

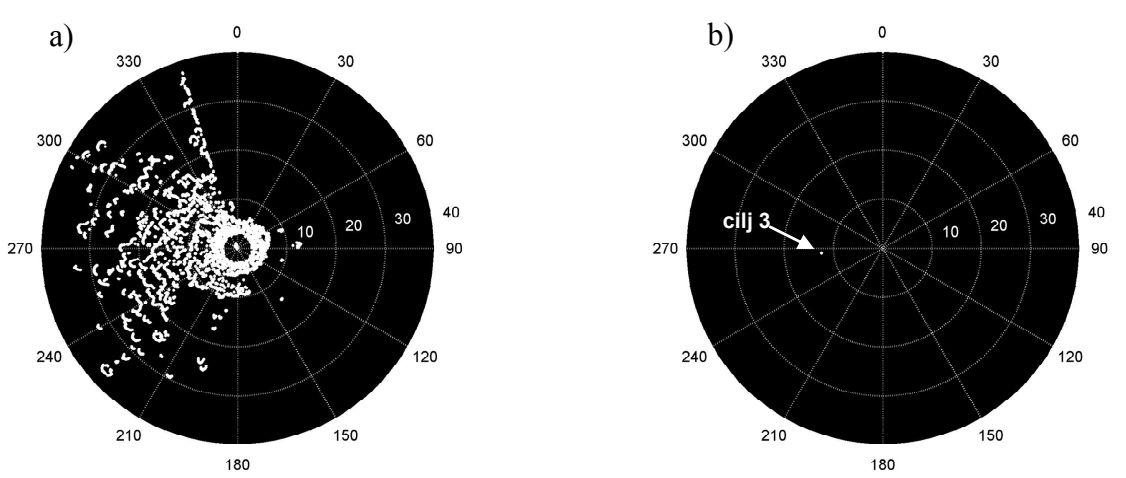

Sl. 18 - Softverski modelovani panoramski pokazivač sa realnim ciljem: a) sirovi video signal; b) sintetički video signal

darskog signala. Realni cilj se lako uočava na azimutu $268^{\circ}$ i daljini $12,5 \mathrm{~km}$.

$\mathrm{Na}$ panoramskom pokazivaču (slika 18a) pri prikazivanju sirovog video signala nemoguće je primetiti cilj. Kada se na pokazivaču prikaže sintetički video signal, realni cilj se jasno uočava na istim koordinatama kao na slici $18 \mathrm{~b}$. $\mathrm{Za}$ razliku od prethodne situacije, kada su detektovana dva cilja, pri akviziciji ovog realnog cilja nije bilo lažnih ciljeva.

Svi realni ciljevi detektovani su sa zadatom verovatnoćom lažnog alarma, a njihove proračunate koordinate odgovaraju koordinatama koje je odredio realni radar.

\section{Zaključak}

$\mathrm{Na}$ osnovu prikazanih kvalitativnih rezultata može se zaključiti da realizovani blokovi softverskog radarskog prijemnika dobro emuliraju rad realnog prijemnika radara, što je bio jedan od osnovnih ciljeva ovog rada.

Modelovanjem konvencionalnih radara putem primene koncepta softverskog radara mogu se poboljšati njihove performanse. Realizacijom ove ideje stvara se pogodna platforma za unapređivanje karakteristika postojećih konvencionalnih radara primenom modernih tehnika obrade radarskog signala. $\mathrm{Na}$ osnovu ove realizacije moguće je unaprediti karakteristike postojećeg radara koje se odnose na precizne estimacije brzine detektovanih pokretnih ciljeva. Primenom koncepta softverskog radara može se povećati fleksibilnost konvencionalnih radara, kao i implementirati potpuno nove funkcije koje znatno unapređuju njegove performanse.

Literatura:

[1] Ivković, D.: Koncept softverskog radara, VTG br. 1, MO RS Vojnoizdavački zavod, 2007.

[2] Ivković, D.: Modifikacija konvencionalnih radara na bazi koncepta softverskog radara, VTG br. 2, MO RS Vojnoizdavački zavod, 2007.

[3] Reed, J. H.: Software Radio, Comunications Enginering and Emerging Technologies, Prentice-Hall PTR, 2002.

[4] Grydeland, T.: Interferometric and high time-resolution observations of Naturally Enhanced Ion-Acoustic Echoes at the EISAT Svalbard Radar: Software radar and Incoherent Scattering, Doctor Scientiarum Dissertation, Faculty of Science Department of Pfysics, University of Tromso, 2003.

[5] Chung-Yi, C.: Modeling and simulation of a search radar receiver, Naval Postgraduate School Monterey California, septembar 1996.

[6] Grydeland, T.: Software radar signal processing, Annales Geophysicale, 2004.

[7] Popović, M.: Digitalna obrada signala, Nauka, Beograd, 1996.

[8] Schleher, D. C.: MTI and Pulsed Doppler Radar, Artech House, USA Norwood, 1991. 